\title{
Indonesian contractors' practices towards sustainable procurement principles for green building projects
}

\author{
Sapto Nugroho Sukardi1, ${ }^{1,}$ and Muhamad Abduh ${ }^{2}$ \\ ${ }^{1}$ Magister Study Program of Civil Engineering, Faculty of Civil and Environmental Engineering, Institut Teknologi Bandung, Bandung, \\ Indonesia \\ ${ }^{2}$ Construction Engineering and Management Research Group, Faculty of Civil and Environmental Engineering, Institut Teknologi \\ Bandung, Bandung, Indonesia
}

\begin{abstract}
Sustainable practices in Indonesia's construction industry have been considered and implemented in green building projects, even though they are not yet enforced by specific regulations on the practices, especially for procurement processes by the contractors. It is believed that the contractors' procurement for selecting subcontractors and suppliers could boost the implementation of sustainability in construction industry since most construction companies deliver majority of their works through their supply chains. This paper presents the comparison between the sustainable procurement principles to the Indonesian contractors' practices in procuring subcontractors and suppliers of their supply chains to support their green building projects. By so doing, the study would measure the compliance of sustainable procurement principles and practices by the Indonesian contractors. For this purpose, the ISO 20400, which is a flexible framework for sustainable procurement were used. The study was conducted using an integrated approach of grounded theory and qualitative data analysis based on a semi-structured interview to 3 large state-owned contractors in Indonesia that have been involved in green building projects. The results show that all contractors have the same level of sustainable procurement practices where the sustainable elements in its procurement process are still in the initiation stage and there are some sustainable procurement resources already existed in the practices that could support further implementation. This study provides the first comprehensive insight into the comparison between the initial sustainable procurement practices by Indonesia's contractors to the ISO 20400. The contribution of this study could be used by Indonesian contractors to improve their sustainable procurement practices for green building projects or other sustainable projects in the future.
\end{abstract}

\section{Background}

Generally, there are 3 main parties involved in the construction project which are owner/client, consultant, and contractor. These parties have different aims and specializations while they're working together to deliver a final product [1]. For most projects, the client selects the contractor, and then the selected contractor selects providers of goods and contractors [1]. These providers are subcontractor and supplier. In this paper, subcontractor is defined as a party which provides specific services, while supplier is defined as a party which provides supplies of materials and construction equipment.

The construction industry consumes about 40 percent of the global material and produces almost 25 percent of the global waste for creating and operating buildings [1]. The usage of construction resources could lead to environmental degradation, climate change, resource depletion, and persistent global poverty [2].
Consequently, awareness has raising among policymakers, stakeholders, and non-governmental organizations to make sustainability as a main objective in construction project [1].

To integrated sustainability in construction process, all parties involved should have the same definition of values. However, it has been explained before that parties involved in construction project have different objectives. Thus, a focus attention should be given to the procurement process since parties involved in construction project are procured through procurement process.

It is believed that the contractors' procurement for selecting its supply chain consists of subcontractors and suppliers could boost the implementation of sustainability in construction project. McCarthy (2017) explained that to deliver sustainability, organizations should deliver them through their supply chain since 40 percent to 80 percent of the organization revenue or funds go to the supply chain. This shows the importance of supply chain procurement towards delivering sustainability in

\footnotetext{
Corresponding author: msaptonugroho@gmail.com
} 
construction process.

Sustainable procurement is defined by ISO 20400 as procurement that has the most positive environmental, social and economic impacts possible across the entire life cycle and that strives to minimize adverse impacts [3]. Best practice of sustainable procurement in construction project was shown in London 2012 Olympic Games. At the initiation stage, it was determined that sustainability was at the highest level of the organization which was the board-level issue [4]. There is also the Olympic Delivery Authority (ODA) which is a non-government executive body to ensure sustainability exists in London 2012 [4].

In Indonesia, a formal sustainability initiative has been started by the Ministry of Public Works in 2009 launching Agenda 21 for Sustainable Construction in Indonesia [5]. There are also several regulations which supports the implementation of sustainable construction in Indonesia. However, there are still no clear guidelines regarding the implementation [6].

Sustainable procurement recently being regulated in chapter 68 of the Presidential Regulation no. 162018. However, most contractors still using the old regulation, the Presidential Regulation no. 54 2010, as their procurement guidelines with some company policies adjustment. The Presidential Regulation no. 542010 didn't mention specifically about sustainable procurement, but there is a clause promoting green procurement embracing the sustainability triple bottom line which are social, economy, and environment. This means that the sustainable procurement principal already been planted in general procurement process in Indonesia.

Even though there isn't any obligatory or enforcement from the government, the practitioners have been beginning to consider sustainable practices, especially in green building projects [5]. The procurement process for the subcontractors and suppliers by the green building contractors merely adapting the Presidential Regulation no. 542010 with several adjustments for the specification complying the client's requirements and the green listing from GBCI (Green Building Council Indonesia) [5,7]. Unfortunately, this sustainable procurement practice wasn't fully supported since the green materials are still lacking and there's no green subcontractor in Indonesia $[5,7]$.

Currently, there's no clear guidelines for contractors to implementing sustainable procurement. Although the new regulation of sustainable procurement has just been released in the Presidential Regulation no. 16 2018, it's mainly focusing on the public procurement and the clauses aren't detail enough. Therefore, this paper attempts to analyze how Indonesian contractors' practices towards sustainable procurement principles for green building projects compared to ISO 20400 which is the flexible framework for sustainable procurement. Based on those statements, there are two research questions in this study appears as follows:

RQ1: How does the green building contractors procure their subcontractor and suppliers?

RQ2: Are the procurement practice by the green building contractors comply to the ISO 20400 ?

This study provides the first comprehensive insight into the comparison between sustainable procurement practices by Indonesia's contractor companies and ISO 20400. It is anticipated that the results of this study could be used by contractor companies to improve their sustainable procurement practices for green building projects or sustainable projects in the future.

\section{Research methodology}

The primary data of this research came by conducting an in-depth semi-structured interview which was recorded and then interpreted to measures the compliance of a practice according to the selected standard. In this research, qualitative approaches for data analysis are considered the most appropriate methods for analysing this type of data because the study does not depend on specific variables for analysis, but rather on concepts and meanings. Therefore, the objective of this study is to draw conclusions based on an actual practice compared to the ideal practice described in the standard.

In order to achieve reasonable conclusions, an effective qualitative data collection protocol should use a systematic process for data collection and also a planned method and documentation for data analysis [9]. Grounded theory method was used in this research involving the process of microanalysis and open-coding technique to define the attributes of the research instrument which are categories, dimensions, and indicators from the selected standard. These attributes were used as a foundation to develop a questionnaire for the semi-structured interviews and basis analysis to obtained conclusions and findings from the data.

ISO 20400 which is the standard in this research and the semi-structured interviews were analysed using the steps depicted in Fig.1. The ISO 20400 is a flexible framework for sustainable procurement which includes procedures and suggestions for the organization for their procurement practices that were used in this research as a standard practice. The semi-structured interviews were conducted with green building contractors and the results were used to learn in-depth about the current sustainable procurement practice and compare the practices to the ISO 20400.

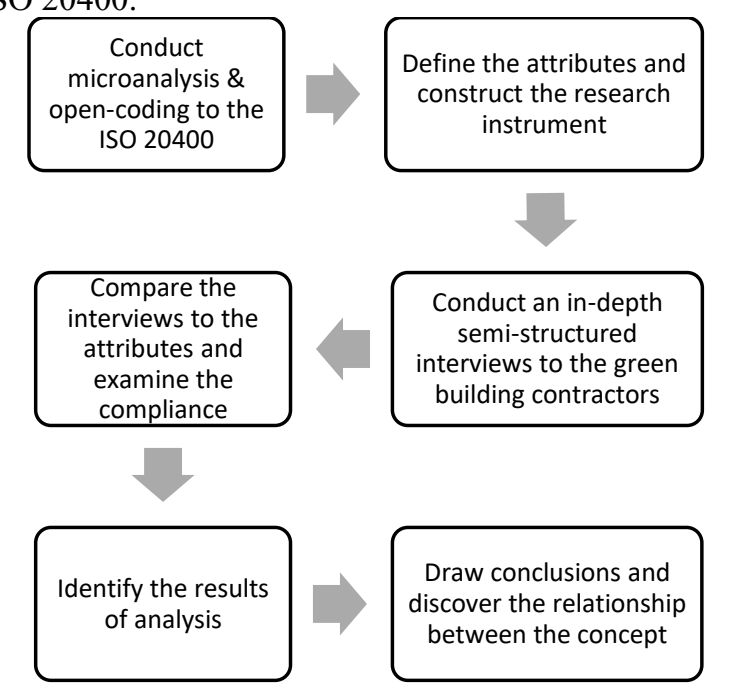

Fig. 1. Data analysis process using the appropriate grounded theory techniques 
Table 1. Open-Coding Results from ISO 20400

\begin{tabular}{|c|c|c|c|c|c|c|}
\hline \multirow{2}{*}{ No. } & \multirow{2}{*}{ Category } & \multirow{2}{*}{ Code } & \multirow{2}{*}{ Dimension } & \multicolumn{3}{|c|}{ Indicator } \\
\hline & & & & Sustainability & Resources & Total \\
\hline \multirow[t]{8}{*}{1} & Organization & 1.1 & Initiator & 2 & - & 2 \\
\hline & & 1.2 & Accountability & - & 2 & 2 \\
\hline & & 1.3 & Regulation & 1 & - & 1 \\
\hline & & 1.4 & Policy & 3 & 2 & 5 \\
\hline & & 1.5 & Planning & 7 & - & 7 \\
\hline & & 1.6 & Implementation & 8 & 10 & 18 \\
\hline & & 1.7 & Tools & 4 & 2 & 6 \\
\hline & & 1.8 & $\begin{array}{l}\text { Sustainability Information } \\
\text { Update }\end{array}$ & 2 & 2 & 4 \\
\hline \multirow[t]{2}{*}{2} & Specification & 2.1 & Sustainability Criteria & 4 & 4 & 8 \\
\hline & & 2.2 & Determining the Requirements & 2 & 6 & 8 \\
\hline \multirow[t]{5}{*}{3} & Selection & 3.1 & Selection Process & - & 4 & 4 \\
\hline & & 3.2 & Pre-qualification & 1 & 2 & 3 \\
\hline & & 3.3 & Tender & - & 2 & 2 \\
\hline & & 3.4 & Rating Method & 1 & 3 & 4 \\
\hline & & 3.5 & Award Stage & 1 & - & 1 \\
\hline \multirow[t]{2}{*}{4} & Contract & 4.1 & Sustainability Promotion & 10 & 2 & 12 \\
\hline & & 4.2 & Partnership Arrangement & 1 & 10 & 11 \\
\hline \multirow[t]{3}{*}{5} & Evaluation & 5.1 & Contract Evaluation & - & 1 & 1 \\
\hline & & 5.2 & Reporting & 3 & 9 & 12 \\
\hline & \multicolumn{3}{|c|}{ Total } & 50 & 61 & 111 \\
\hline
\end{tabular}

\section{Constructing the instrument}

\subsection{Defining the instrument attributes}

ISO 20400 was examined using microanalysis which is a detailed line-by-line investigation to produce initial categories. Each category has its own dimensions that define the range of possible values of category [9]. To measures the compliance of the contractor's practices compared to the ISO 20400, indicators were defined from each dimension. There are two type of indicators in this research which are sustainability indicator and resources indicator. These categories, dimensions, and indicators are called attributes and were used as a foundation of the questionnaire for the semi-structured interviews.

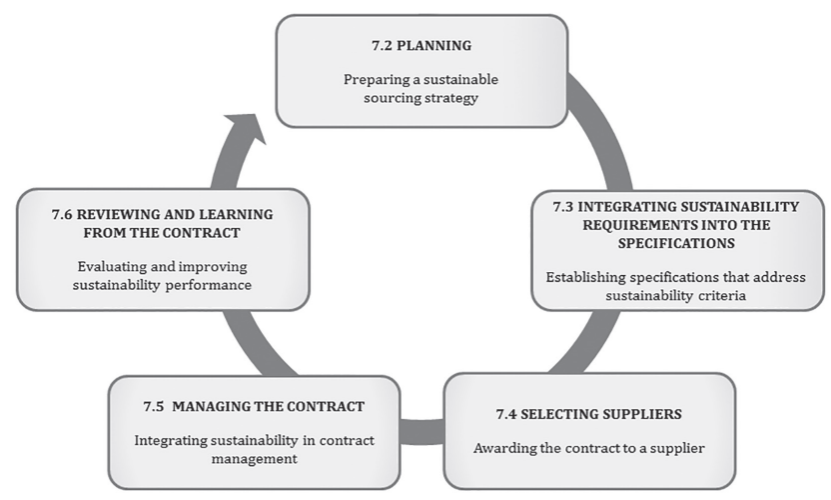

Fig. 2. Integrating sustainability into the procurement process (Source: ISO 20400)

While examining the ISO 20400, an open-coding technique was performed to discover categories, dimensions, and indicators. In open-coding, the categories and their dimensions are discovered and titled. The categories were developed from a clause in ISO 20400, 7.1 Building on the existing process. This clause explains the implementation of sustainable procurement based on the existing process. There are 5 main processes in the clause depicted in Fig. 2 which are Planning, Integrating Sustainability Requirements to the Specifications, Selecting Suppliers, Managing the Contract, and Reviewing and Learning from the Contract. These 5 main processes are integrated with the results of microanalysis \& open-coding of the whole content of ISO 20400 and turned into 5 main categories in this research which are Organization, Specification, Selection, Contract, and Evaluation. The other results of ISO 20400 open-coding produce a total of 19 dimensions and 111 indicators as shown in Table 1.

\subsection{Compliance measurement}

To determine the compliance of the contractor's sustainable procurement practice compared to the ISO 20400, a rubric of scores was developed for assessing respondent's answers during the semi-structured interview. This qualitative research method is called scaling (Miles and Huberman 1994), whereby the respondent's answers are scaled to consistently appraise and compare the practice from the ISO 20400. Each indicator has a range of score from $0-1$, where 1 means the answer matches with the indicator, and 0 means the indicator hadn't been added to the current practice.

To determine the level of implementation, all the 111 indicators were measured by their scores and then divided by the total of maximum scores to get the compliance percentage. The level of implementation itself was defined from the characteristics of the distribution of the

\footnotetext{
* Corresponding author: msaptonugroho@gmail.com
} 
Table 2. Level of Compliance Definition

\begin{tabular}{cl}
\hline $\begin{array}{c}\text { Range of } \\
\text { Level }\end{array}$ & \multicolumn{1}{c}{ Description } \\
\hline $0 \%-20 \%$ & $\begin{array}{l}\text { There's no sustainable practice found in the current process, the resources aren't supporting the } \\
\text { sustainable procurement implementation. }\end{array}$ \\
$20 \%-40 \%$ & $\begin{array}{l}\text { Sustainability starting to be considered in the practice, resources are being prepared to support } \\
\text { the sustainable procurement implementation. }\end{array}$ \\
$40 \%-60 \%$ & $\begin{array}{l}\text { Sustainability implementation is in the initial stage, some of the resources support the } \\
\text { sustainable procurement implementation. }\end{array}$ \\
$60 \%-80 \%$ & $\begin{array}{l}\text { Some of the sustainable practices have been implemented in the current practice, the resources } \\
\text { support the sustainable procurement implementation. }\end{array}$ \\
$80 \%-100 \%$ & $\begin{array}{l}\text { The sustainable practices have been splendidly implemented in the current practice, all } \\
\text { resources fully support the sustainable procurement implementation. }\end{array}$ \\
\hline
\end{tabular}

sustainability and resources indicators of each dimension from the collected data. The level of implementation shown in Table 2.

\section{Results}

A total of 44 questions were group into seven sets focus on the contractor's practice of sustainable procurement. Five sets are the main categories from the open-coding, while the other 2 sets are about contractor's opinion and understanding regarding the sustainable procurement.

Contractor companies in this research were selected from the listed green building from GBCI official website. Twenty green buildings were found on the website. The contractors of the green building projects were contacted for their interview availability for this research. Three state-owned contractors are available for interview which will be referred in this paper as Contractor A, Contractor $\mathrm{B}$, and Contractor $\mathrm{C}$. All of the respondents from the selected contractors are senior level personnel of the procurement department.

Semi-structured interviews conducted by asking questions from the questionnaire. During the interview, a recording device was used to record all of respondent's answers. The recorded answers then were interpreted and compared with the established indicators for compliance measurement and then classified into categories and dimension to be analysed. Table 3 shows the compliance of the sustainable procurement implementation for each contractor in category level. The dimension level of compliance shown in Fig. 3. The average compliance of each indicators in category level shown in Fig. 4.

Data from table 3 summarize that the level of sustainable procurement practice for all of the contractors is at the same level. The compliances are in the range of $40 \%-60 \%$ which means that the sustainability implementation is in the initial stage and some of the resources support the sustainable procurement implementation. Breaking down to the dimension level, in Fig. 3 shows that the compliance for each dimension varies from $0 \%$ to $100 \%$. It shows that some of the resources could support the sustainable procurement while the other resources couldn't.

Looking at the Fig. 4, it shows that the compliance of resources indicators is affecting the results. The statistic shows that resources indicator compliance leading the domination with a $100 \%$ level of compliance in several dimensions while most of the sustainability compliance levels are less than $20 \%$.

Table 3. Category Level of Compliance

\begin{tabular}{cccc}
\hline Category & Contractor A & Contractor B & Contractor C \\
\hline Organization & $47.64 \%$ & $47.64 \%$ & $46.92 \%$ \\
Specification & $60.42 \%$ & $60.42 \%$ & $60.42 \%$ \\
Selection & $86 \%$ & $84 \%$ & $79 \%$ \\
Contract & $47.83 \%$ & $47.83 \%$ & $44.57 \%$ \\
Evaluation & $69.23 \%$ & $69.23 \%$ & $69.23 \%$ \\
\hline Total Compliance & $\mathbf{5 6 . 3 8 \%}$ & $\mathbf{5 6 . 1 6 \%}$ & $\mathbf{5 5 . 1 1 \%}$ \\
\hline
\end{tabular}




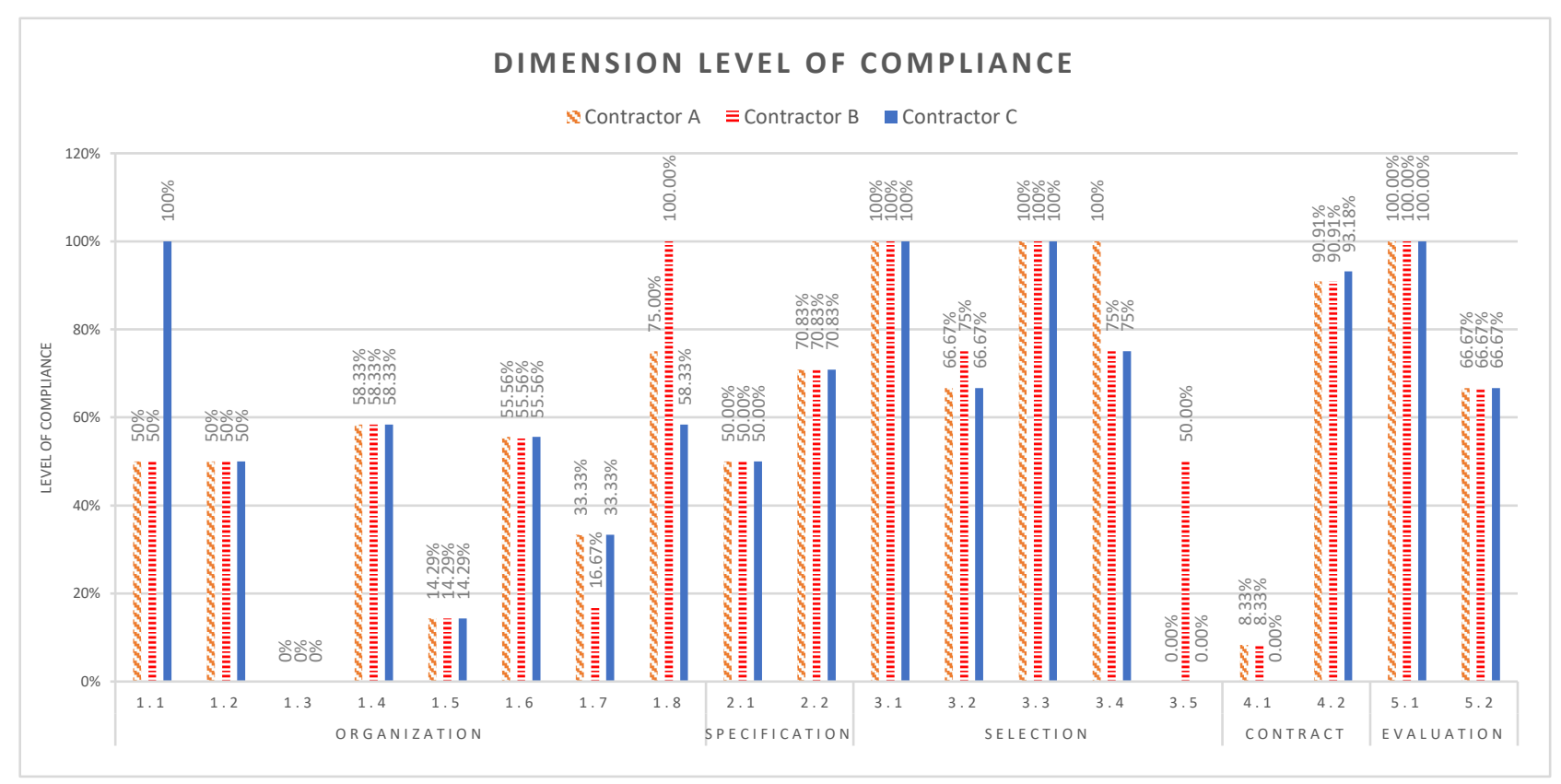

Fig. 2. Demographic of Dimension Level of Compliance

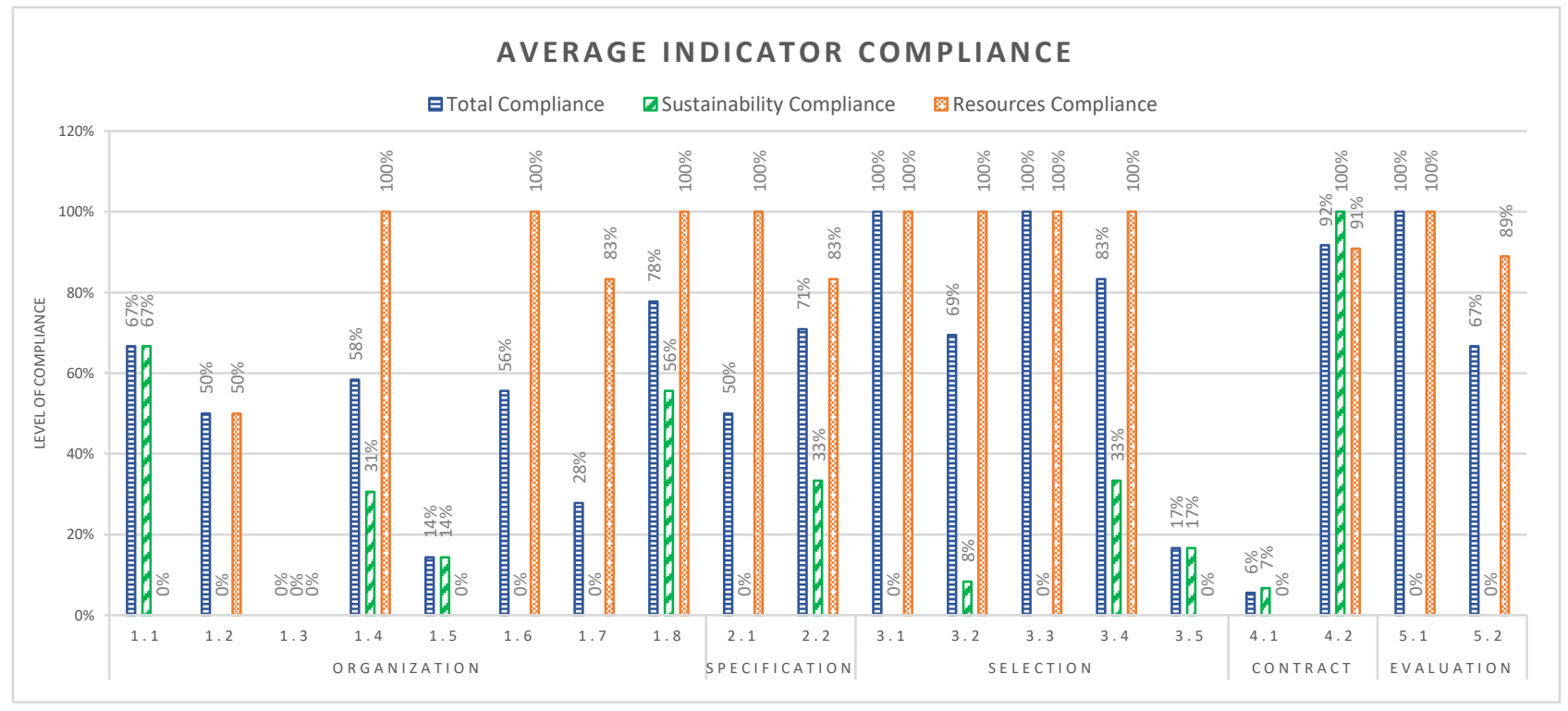

Fig. 3. Demographic of Average Indicator Compliance

\section{Discussion}

The implementation process of sustainable procurement in ISO 20400 is applicable to any organization and takes into account the particular context and characteristics of each organization, scaling the application of the concepts to suit the size of the organization [3]. The process is started by ensuring the value of sustainability is well established in the organization's goals. The process is continued to the integration of sustainability at a strategic level within the procurement practices, management technique, and the personnel. The implementation defined in ISO 20400 creates a cyclical process with a continuous improvement where the evaluation of the previous implementation becomes a consideration in the future planning.
One important aspect that emerged from the interviews was that respondents were not clear about how to define whether their practice match with the sustainable procurement practice from ISO 20400. Their differences were partly due to their knowledge about sustainable procurement which is still a new concept in the construction industry. The ISO 20400 itself was designed for universal organization thus the requirements listed in the clauses are quite general which could be multiinterpreted by the respondents regarding their company practices.

Even though all of the respondents have their own idea of the sustainable procurement practices, they all are stated that their company doesn't differ the procurement process either for green building projects or general projects. This results in the compliance level of all the 
respondents are at the same level where the sustainability implementation is in the initial stage and some of the resources support the sustainable procurement implementation. This condition also leads the respondents to resort to green standards, such as green list material from GBCI since there's no specific green/sustainable standards from the company, and the requirement from the client to determine a green/sustainable specification and then asked suppliers to comply.

The absence of sustainability in the current practice of the respondents still give them a score of around $50 \%$ of compliance level. This suggests that most of the processes in the ISO 20400 are existed in general procurement. It also indicates that the current resources in the procurement department of the respondent's company could support the implementation of sustainable procurement.

Although some of the resources could support the implementation it would be useless if it's not supported by a high commitment from the company itself. It was found that all of the contractors still lack awareness regarding the urgency of sustainable procurement even though sustainability has been stated in the company mission statement. The focus of the sustainability initiatives still in the construction department while the procurement department still left behind which was shown by the absence of sustainability training program for the procurement personnel, no clauses to promoting sustainability in partnership arrangement in the contract, and there's no specific regulation about sustainable procurement. This is consistent with previous literature that the lack of knowledge and regulations has become barriers to implement sustainable procurement [10].

Lack of commitment from clients is one of difficulty in providing sustainable products [1]. In construction projects, the requirements usually established by the client, thus if the client doesn't include sustainable criteria in the requirement, the contractors wouldn't put it on their purchasing decision since it could raise their cost expenses. Another difficulty in delivering sustainability also found by Abduh [5] who mention that the availability of green/sustainable resources on the market is limited. As a result, contractors may easily switch to non-sustainable resources. All those findings similar to the findings in this research where the contractors tend to not put sustainable criteria in their purchasing decision unless it's on the client's requirement.

Based on the findings in this research, it can be concluded that some improvements are needed in order to maturate sustainable procurement practice in Indonesia, which are:

1. The contractor should have a high commitment to implement sustainability by including sustainable elements in their corporate culture and in their supply chains. High commitment from the contractor would make them as a pioneer of sustainable construction resulting the market for sustainable construction increasingly open that could boost the implementation of sustainable procurement.

2. High commitment from the client is also needed in order to push the contractor to put sustainable criteria in their purchasing decision. If it's needed, the client should be involved in the procurement process or recruit a representative as a sustainability assurance that works with the contractor to ensure sustainable practices in the procurement process.

3. Competency and training program definitions for procurement personnel to be able to conduct as required by sustainable procurement are needed. Certification could be one of the strategic ways to increase number of sustainable personnel to support the implementation [5].

4. A regulation to promote sustainable procurement is needed to be made by the government. Sustainable procurement should become a mandatory requirement in the infrastructure projects thus all parties could understand the impact and the urgency of the implementation. The need for high commitment from the government. The government should also provide a positive compensation to the client or contractor for implementing sustainability in the life cycle of the construction project so that the construction industry would be encouraged to implement the sustainability [7].

5. Innovative initiatives form supplier \& subcontractors are needed to increase availability of sustainable products in the market. This initiative could also make sustainable products become an attractive option to the contractor \& client.

\section{Conclusion}

This study provides comprehensive insight into the comparison between sustainable procurement practices by Indonesia's contractor companies and ISO 20400. The study was conducted using an integrated approach of grounded theory and qualitative data analysis based on a semi-structured interview with 3 large state-owned contractors in Indonesia that have been involved in green building projects. The results of open-coding from ISO 20400 produce 5 categories, 19 dimensions, and 111 indicators which will be used to assess the compliance level of sustainable procurement practices by the contractors. The assessment results are then analyzed and compared to find out the barriers and solutions.

The level of sustainable procurement practice for all of the contractors is in the range of $40 \%-60 \%$ which indicates that the sustainability implementation is in the initial stage and some of the resources support the sustainable procurement implementation. They still lack of commitment which was shown by no distinction of procurement process either for green building projects or general projects, the absence of sustainability training program, and no clauses to promoting sustainability in partnership arrangement in the contract. Another difficulty in providing sustainable products by the contractors was caused by the limited availability of sustainable resources, lack of commitment from the client, and the tendency to choose a lower price product/service.

Improvements are needed for better implementation of sustainable procurement by the contractors. It requires a high commitment not only just from the contractor, but 
also the client who have the highest authority in the construction project so that sustainability could be well integrated in the procurement process. Government also play an important role as a regulator that could promotes sustainability in every construction project. Innovative initiatives are needed from the supplier and subcontractor which could make sustainable products become an attractive option to the contractor \& client.

\section{References}

1. S. Mokhlesian, How Do Contractors Select Suppliers for Greener Construction Projects?. The Case of Three Swedish Companies. MDPI Journal of Sustainability, Vol. 6 (2014)

2. S. Brammer and H. Walker, Sustainable Procurement In The Public Sector: An International Comparative Study. International Journal of Operations \& Production Management Vol. 31 No. 4, pp. 452-476 (2011)

3. International Organization for Standardization. Sustainable procurement - Guidance ISO 20400:2017. International Organization for Standardization (2017)

4. Department for Environment Food \& Rural Affairs. London 2012 Olympic and Paralympic Games The Legacy: Sustainable Procurement For Construction Projects A Guide. (2013)

5. M. Abduh, Green Construction Supply Chains for Supporting Green Buildings in Indonesia: Initial Findings and Future Developments. International Conference on Construction in a Changing World, Srilanka (2014)

6. S. N. Sukardi, Kebutuhan Pengadaan Berkelanjutan untuk Kontraktor ke Subkontraktor dan Supplier untuk Mendukung Konstruksi Berkelanjutan di Indonesia. Will be published in Jurnal Pengadaan Vol. 6 (2018)

7. P. Herdianti, Kajian Proses Pengadaan Subkontraktor dan Supplier Rantai Pasok Konstruksi Untuk Mendukung Pelaksanaan Bangunan Hijau. Institut Teknologi Bandung (2015)

8. Department for Environment Food \& Rural Affairs. London 2012 Olympic and Paralympic Games The Legacy: Sustainable Procurement For Construction Projects A Guide. (2013)

9. R. Y. AlMaian, A Qualitative Data Analysis for Supplier Quality-Management Practices for Engineer-Procure-Construct Projects. ASCE Journal of Construction Engineering \& Management 142(2): 04015061. (2016)

10. Direktorat Iklim Usaha dan Kerjasama Internasional LKPP. Sustainable Public Procurement. Jurnal Pengadaan Vol. 3, No. 3. (2013) 